\title{
DNA Polymerase Switching on Homotrimeric PCNA at the Replication Fork of the Euryarchaea Pyrococcus abyssi
}

\author{
Christophe ROUILLON, Ghislaine HENNEKE, Didier FLAMENT, Joël QUERELLOU and \\ Jean-Paul RAFFIN*
}

\author{
IFREMER, UMR 6197, Laboratoire de Microbiologie et Environnements Extrêmes, BP 70, \\ F-29280 Plouzané, France. \\ * Corresponding author: Jean-Paul RAFFIN, Ifremer, EEP/LM2E, B.P. 70, 29280 Plouzané, \\ France; Tel.: +332 982245 39; Fax: +332 982247 57; \\ E-mail: jpraffin@ifremer.fr
}

\begin{abstract}
:
DNA replication in Archaea, as in other organisms, involves large protein complexes called replisomes. In the Euryarchaeota subdomain, only two putative replicases have been identified, and their roles in leading and lagging strand DNA synthesis are still poorly understood. In this study, we focused on the coupling of proliferating cell nuclear antigen (PCNA)-loading mechanisms with DNA polymerase function in the Euryarchaea Pyrococcus abyssi. PCNA spontaneously loaded onto primed DNA, and replication factor $C$ dramatically increased this loading. Surprisingly, the family B DNA polymerase (Pol B) also increased PCNA loading, probably by stabilizing the clamp on primed DNA via an essential motif. In contrast, on an RNA-primed DNA template, the PCNA/Pol B complex was destabilized in the presence of dNTPs, allowing the family D DNA polymerase (Pol D) to perform RNAprimed DNA synthesis. Then, Pol D is displaced by Pol B to perform processive DNA synthesis, at least on the leading strand.
\end{abstract}

Keywords: Archaea; DNA replication; DNA polymerase switching; PCNA loading; RF-C 


\section{INTRODUCTION}

DNA replication occurs by a functionally conserved mechanism in all organisms, including

Bacteria, Eukarya, Archaea, and viruses, ${ }^{1,2}$ and is tightly linked to the maintenance of genome stability. ${ }^{3}$ DNA replication proceeds in three stages: initiation at the replication origins, DNA synthesis at the replication fork (elongation), and termination. Each of these processes involves different and successive stable or transient protein-protein and protein-DNA complexes; elongation depends on a large nucleoprotein assembly called the replisome. ${ }^{4}$ DNA synthesis typically involves a protein triad composed of a clamp-loader, a sliding clamp, and a replicative DNA polymerase. In Eukarya and Bacteria, the clamp-loader catalyzes the assembly of the ring-shaped clamp around primer DNA in an ATP-dependent process; a replicative DNA polymerase is subsequently recruited and catalyzes highly processive DNA synthesis. ${ }^{5,6}$ In Archaea, it has been reported that the clamp-loader does not require ATP hydrolys is to perform functional loading of the PCNA clamp. ${ }^{7}$

In E. coli, the chromosomal replicase is DNA polymerase III, and the three major functional units comprise ten different proteins. ${ }^{8-10}$ The structures of the clamp $(\beta)^{11}$ and the clamploader $(\gamma \text {-complex })^{12}$ are known. The replisome of the T4 bacteriophage, which involves a clamp (gp45), clamp-loader (gp44/gp62) and DNA polymerase (gp43), is also well characterized. ${ }^{13-16}$

A fascinating relationship was noted when the Eukarya and Archaea DNA replication proteins were compared. Complete sequencing of the archaeal genome ${ }^{\S}$, which is still an active field of study, ${ }^{17}$ identified homologues of PCNA and RF-C, which are the eukaryal clamp and clamploader, respectively. Further, proteins involved in replication are functionally conserved throughout evolution, while sometimes showing little or no sequence similarity. Thus, DNA polymerase $\delta$ was shown to be stimulated by Thermococcus fumicolans $\mathrm{PCNA},{ }^{18}$ the mammalian clamp-loader was able to interact with the Pyrococcus furiosus $\mathrm{PCNA},{ }^{19}$ and 
human PCNA could be loaded onto DNA by the Pyrococcus abyssi RF-C complex. ${ }^{7}$ The archaeal DNA replication proteins are simpler than their eukaryal counterparts, i.e. there are fewer protein subunits involved. For example, the eukaryal RF-C complex has five different subunits, ${ }^{20}$ the archaeal homologue has only two, ${ }^{21-23}$ and the Methanosarcina acetivorans RF-C homologue is, uniquely, a three subunit clamp-loader. ${ }^{24}$ In addition, the archaeal RF-C large subunit lacks a large part of the $\mathrm{N}$-terminal sequence of the eukaryal homologue, ${ }^{7}$ which should be taken into account when comparing the structures of the two clamp-loader complexes. $^{25-28}$

Compared to their eukaryotic homologues, the archaeal replication factors display unique functional properties. Stimulation of archaeal DNA synthesis by PCNA on a circular DNA template was observed without the clamp-loader..$^{21,29,30}$ This was attributed to spontaneous loading that could be explained by weaker intermolecular interactions within PCNA monomers. ${ }^{31}$ Moreover, the residues that maintain the toroidal structure of the archaeal PCNA were identified. ${ }^{32}$ These results indirectly showed that the archaeal PCNA is able to load onto DNA in the absence of the clamp-loader.

When looking at the archaeal domain, it is clear that significant differences can be found within the main sub-domains, i.e. in the Euryarchaea and the Crenarchaea. Indeed, up to three PCNA homologues have been identified in Crenarchaea ${ }^{30,33}$ that form a heterotrimer in vivo, ${ }^{34}$ whereas only one homologue was found in Euryarchaea. In Archaea as well as in Eukarya and Bacteria, PCNA not only enhances the processivity of DNA replicases, but can also be conceptualized as a moving platform on which protein switches occur depending on the affinity of interacting factors, the structure of DNA, informational events, and cell cycle regulation. ${ }^{35}$ Since PCNA is a trimer, it is possible that up to three protein factors could be bound at the same time. Alternatively, the factors may bind sequentially, depending on their functions during the cell cycle. In E. coli, protein-protein interaction studies demonstrated 
that the DNA polymerase and clamp-loader actually bind to the same face of the clamp and, in fact, compete with one another. ${ }^{36}$ It has been proposed that during Okazaki fragment maturation, proteins involved in this process compete for binding to the PCNA. ${ }^{37,38}$ More recently, studies of the interplay between DNA replication and DNA repair suggest a modification of the composition and the processivity of the PCNA-protein complex, specifically the switching of the DNA polymerase involved in the process. ${ }^{35,39-41}$ A DNA polymerase switch model was also described for the establishment of cohesion between sisters chromatids. ${ }^{42}$

Crenarch aea possess several (up to three) family B monomeric DNA polymerases ${ }^{43,44}$ whereas Euryarchaea possesses one family B and one heterodimeric DNA polymerase belonging to family $\mathrm{D}$ that has only been found in this sub-domain. ${ }^{45-48}$ We have previously shown that the two DNA polymerases from P. abyssi, PabPol B and PabPol D, were required for DNA replication and that only Pol D displayed RNA elongation and RNA stranddisplacement activity in the presence of $\mathrm{PCNA}^{49}$ In the current study, we investigated PCNAloading and recruitment of the two putative replicases. The subunit interactions with in the complexes, coupled with functional studies, allows us to propose that DNA polymerase switching might occur on the loaded PCNA during euryarchaeal DNA replication. 


\section{RESULTS}

\section{PabPCNA spontaneous loading on primed single-stranded DNA is enhanced at high}

\section{temperature and reinforced by Pab RF-C and PabPol B.}

Up to now, only indirect evidence suggested that archaeal PCNA could load spontaneously on to DNA. Therefore, we analyzed the loading of PabPCNA on to different types of DNA substrate: short primed or non-primed 3'-5' biotinylated DNA template (ssDNA) or primed M13ssc. On the short synthetic substrate, loading was visualized in the absence of PabRF-C (Figure 1(a)). Loading occurred on ssDNA (lanes 2-5) but was more efficient on primed DNA (lanes 6-9). Spontaneous loading of PabPCNA onto primed ssDNA was increased at higher temperatures as demonstrated in Figure $1(\mathrm{~b})$. Indeed, the loading efficiency at $37^{\circ} \mathrm{C}$ was only about $10 \%$ of that measured at $65^{\circ} \mathrm{C}$. Moreover, including a non-biotinylated primed ssDNA as a competitor in the incubation dramatically reduced the loading efficiency: a six-fold reduction was observed at $65^{\circ} \mathrm{C}$. This indicates that the PabPCNA interaction with the DNA template is specific.

Spontaneous loading was also observed using the cross-linking method previously described for human PCNA $^{50}$ with a more physiological template, namely primed M13ssc DNA (Figure 2(a); see control, lane 2). PabRF-C promoted the loading in the absence of ATP (Figure 2(a), lane 3), and either ATP or ATP $\gamma \mathrm{S}$ increased the loading efficiency (Figure 2(a), lanes 4 and 5). However, semi-quan titative analysis clearly showed that ATP did not significantly stimulate the clamp-loading activity of PabRF-C-promoted PCNA loading and that spontaneous loading was about $15 \%$ of the maximal loading efficiency in the presence of RFC and ATPYS (Figure 2(c)).

To check the specificity of the loading, we next performed comparative studies with wild-type PabPCNA and the triple mutant PabPCNA(ded). This mutant could not trimerize (Figure 2(d)), and loading was defective in all conditions tested (Figure 2(a), lanes 6-9). This data was 
supported by an experiment using fluorescently labeled molecules: DNA and PabPCNA colocalize on the gel(Figure 2(b)). Indeed, when superposed, images acquired respectively at 488 and $532 \mathrm{~nm}$ showed co-localization of PCNA and DNA (yellow co-localization signal). In addition, these data conf irmed the specific interaction observed between PabRF-C and PabPCNA loading onto DNA. We concluded that PabPCNA was loaded as a homotrimer and that the technique used for measuring the loading was accurate.

When PabPol B was added to the loading reaction, spontaneous loading of PabPCNA on to circular primed DNA was markedly increased (Figure 2(a), compare lanes 2 and 10, which show a 4-fold increase in loading). With PabRF-C, some increase of loading was also observed, either in the presence (1.2-fold) or absence (2-fold) of ATP (Figure 2(a), compare lanes 3 and 11 and lanes 4 and 12), but not with ATP $\gamma S$ (Figure 2(a), compare lanes 5 and 13). In contrast, $P a b$ Pol D did not enhance PabPCNA loading (data not shown). Moreover, no signal was observed in the presence of $P a b P o l B$ and PabPCNA(ded), indicating that the DNA polymerase interacts only with the homotrimeric PCNA (data not shown).

Taken together, these data show that the trimeric form of PabPCNA spontaneously loads onto DNA and that PabRF-C, together with PabPol B, associates with the ring as a stable complex on primed DNA.

\section{PabPCNA/PabPol B are organized as a competent stable catalytic complex onto primed} DNA, while the presence of an RNA primer is inhibitory.

Since PabPol B stimulated the binding and loading of PabPCNA onto DNA, we added dNTPs into the loading reaction to determine whether a functional complex could form that was able to perform primer elongation. At first, when we used a higher resolution agarose gel, two loading populations were resolved (Figure 3(a)), and the addition of PabPol B increased the two load ing forms on primed and non-primed M13ssc DNA (Figure 3(a), compare 
respectively lanes 6 and 2 with lanes 10 and 11). However, while the signal was increased 9fold on primed M13ssc (compare lanes 2 and 11), the increase was only 2-fold on non-primed DNA (compare lanes 6 and 10). When dNTPs were added to the incubation mixture, primer elongation was efficient. Primer elongation took place only with primed M13ssc DNA (Figure 3(a), compare lanes 12 and 13; Figure 3(b), lane 4), showing that a functional PabPCNA/PabPol B complex formed only on the primed template. The primer elongation product was identified as the upper band, suggesting that the lower band was non-functional. Interestingly, in the presence of the PabRF-C, only one broad, non-distinct band was visible (Figure 3(a), lanes 3-5 and 7-9).

Many DNA polymerases contain a conserved PCNA-binding motif (PIP-box) located at the C-terminus. ${ }^{51}$ We deleted this motif in PabPol B and tested the ability of PabPol B( $\Delta$ pip) to stimulate PabPCNA loading. As shown in Figure 3(b), lanes 5 and 6, the PabPol B( $\Delta$ pip) did not stimulate PCNA loading, and even suppressed spontaneous loading, probably by competing with PCNA on the primer-template junction.

PabPol B stimulated the loading of PabPCNA onto RNA-primed DNA even more than onto the DNA-primed template: the signal increased 3-fold with the RNA primer (Figure 3(b), lanes 8 and 9) and only 1.5-fold with the DNA primer (Figure 3(b), lanes 2 and 3). Interestingly, addition of dNTPs abolished PabPol B-stimu lated loading (Figure 3(b), lanes 9 and 10), and the observed signal was similar to that obtained with PabPCNA alone (Figure 3(b), lane 8). This suggests that in the presence of an RNA-primed template, dNTPs destabilize the PabPol B/PabPCNA complex.

\section{PabRF-C enhances DNA synthesis of short fragments by the PabPol B/PCNA complex but has no effect on the PabPol D/PCNA complex.}


Thus far, we have shown that the PabPol B/PabPCNA complex can be functionally loaded onto primed DNA without clamp-loading by PabRF-C. To further investigate DNA synthesis in the presence of the two accessory proteins, we performed an in vitro DNA primer extension assay using PabPol B and PabPol D. First, we tested the ability of PabPCNA to stimulate PabPol B DNA synthesis on primed M13ssc DNA. As shown in Figure 4(a), PabPCNA clearly enhanced the extension activity of PabPol B in the absence of PabRF-C. The phosphorylated PabPCNA derivative was also active in promoting PabPol B DNA synthesis (Figure 4(a), lane 3), but the ph-PabPCNA(ded) mutant was not active (Figure 4(a), lane 4). The PabPol B primer-extension assay was then performed in the presence of PabRF-C (Figure 4b). Surprisingly, PabRF-C favored the synthesis of short $(<2 \mathrm{~kb})$ DNA fragments (Figure 4(b), lanes 2-3). The effect of PabRF-C on releasing pausing sites in the $0.3-0.5 \mathrm{~kb}$ range and stimulating the accumulation of $\sim 2 \mathrm{~kb}$ fragments was clearly visible when RF-C was added at different times during the incubation (Figure 4c). PabPCNA also stimulated the primer-extension ability of PabPol D (Figure 4(b), lane 13). However, adding PabRF-C to the reaction did not affect DNA synthesis by the PabPol D/PabPCNA complex (Figure 4(b), lanes 14-16). Taken together, these data show that $P a b$ RF-C affects the two Pab DNA polymerases differently, favoring DNA synthesis of short fragments by the Pol B/PCNA complex, while having no effect on the Pol D/PCNA complex.

We next performed a study of the interaction between PabPCNA and PabRF-C in order to determine the effect of ATP hydrolysis. The biotinylated primed 75-mer oligonucleotide was immobilized on streptavidin beads, and complexes with PCNA and RF-C were visualized by Western blot analysis with antibodies specific to PabPCNA or to the PabRF-C small subunit. On this short DNA substrate, PCNA loading was the same in the presence of PabRF-C and either ATP or ATP $\gamma$ S (Figure 5(a), lanes 5-6). However, while PabRF-C was part of the complex in the presence of ATP $\gamma \mathrm{S}$, the PabRF-C signal was weaker in the presence of ATP 
(Figure 5(b), compare lanes 5 and 6), showing that this factor was released upon completion of the load ing process.

\section{DNA polymerases compete for PabPCNA independent of the presence of PabRF-C.}

Since PabRF-C affected only the PCNA-stimulation and DNA synthes is of PabPol B, a competition between Pol B and the clamp-loader for interacting with the PCNA could occur. To investigate this hypothesis, we analyzed the interactions between the partners on a short primed 3'-5' biotinylated DNA template. The experiments were carried out with the same molar ratio for the different proteins, which were sequentially added to the reaction mixture. First, $P a b$ PCNA, PabRF-C, and the two Pab DNA polymerases interacted individually with the DNA template (Figure 6(a), lanes 5-8). In every case, the signal was higher than the background (Figure 6(b), compare lanes 5-8 to lanes 1-4). Second, PabRF-C stimulated binding of PabPCNA (Figure 6(a), compare lanes 5 and 9), resulting in about a 2-fold increase of the signal (Figure $6 \mathrm{~b}$ ). PabPol B, but not $\mathrm{PabPol} \mathrm{D}$, stimulated the binding of PCNA (Figure 6(a) and (b), lanes 5, 10, and 11) and PabPCNA increased the binding of PabPol B (Figure 6(a) and (b), lanes 7 and 10) but not PabPol D (Figure 6(a) and (b), lanes 8 and 11). Third, PabRF-C and PabPol B interacted together on the clamp (Figure 6(a), lane 13), showing that the inhibiting effect of PabRF-C was not related to a PCNA-unloading mechanism. Surprisingly, in the presence of the DNA polymerase, the PabRF-C was not released at the end of the loading process (Figure 6(a) and 6(b), lane 13), contrary to what was observed in the absence of PabPol B (Figure 5). In addition, RF-C was not released in the presence of the catalytic-competent complex Pol D/PCNA/DNA (Figure 6(a) and 6(b), lane 14). Interestingly, when mixing the two DNA polymerases together with PCNA and DNA, PabPol D could not form a stable catalytic complex with PCNA in the presence or the 
absence of PabRF-C (Figure 6(a) and 6(b), lanes 12 and 15), suggesting that the two Pab Pols compete for access to the PCNA platform. 


\section{DISCUSSION}

The mechanism by which DNA polymerases achieve processivity is conserved among Prokarya, Eukarya, Archaea, and viruses. The DNA sliding clamp (the $\beta$ subunit of DNA polymerase III holoenzyme in E. coli, gp45 in bacteriophage, and PCNA in Eukarya and Archaea) endows the replic ative polymerase with high processivity. The clamp loader (the $\gamma$ complex in E. coli, gp44/62 in T4 bacteriophage, and RF-C in Eukarya and Archaea) in teracts with the clamp and uses ATP to drive clamp-loading on to primed DNA. The replicative DNA polymerases recruited for DNA synthesis are pol III in E. coli, pols $\delta$ and $\varepsilon$ in Eukarya, at least one of three pols B in Crenarchaea, and pols B and D in Euryarchaea. When more than one replicative polymerase is present, questions about their involvement in leading or lagging

strand synthesis have been raised. ${ }^{52-55}$ For the Euryarchaea replication fork, the action of DNA polymerases has recently been investigated in P. abyssi. ${ }^{49}$ Since only PabPol D, but not PabPol B, displayed PCNA-dependent RNA strand displacement in the conditions tested, it was assumed that both DNA polymerases were required for DNA replication in P. abyssi, with PabPol D involved at the lagging strand.

In this study, we investigated how the clamp-loading mechanism is coupled to DNA synthesis in the archaeon P. abyssi. We focused on mechanisms that could modulate the interaction of the two DNA polymerases, PabPol B and PabPol D, with the loaded PabPCNA. We first used cross-linking ${ }^{50}$ and pull-down experiments to show that PabPCNA spontaneously loaded onto synthetic short DNA templates as well as onto physiological DNA templates. Up to now, only ind irect evidence had been obtained regarding the spontaneous loading of archaeal PCNA. ${ }^{21}$ The loading was particularly efficient at high temperature $\left(65^{\circ} \mathrm{C}\right)$ and with a primed template, which is in accordance with the physiological function of PCNA. By quantifying the amount of loaded PCNA, we found that about $15 \%$ loaded spontaneously compared to the amount loaded in the presence of PabRF-C and ATPYS; the 
clamp-loader was thus required for improving loading efficiency. As expected, no loading on any template was observed using mutant PabPCNA defective in trimerization. This mutant PCNA was also unable to stimulate DNA synthesis by the DNA polymerases. Taken together, these data suggest that the RF-C is not required in vivo for loading of the archaeal PCNA. Interestingly, this implies that in Archaea, PCNA can be loaded onto circular DNA without energy (i.e. without ATP hydrolysis). Comparable results were obtained using primed M13 single-stranded DNA and the double biotinylated 75-mer, showing that spontaneous loading could not be attributed to the presence of linearized M13 DNA. In addition, the M13 circular DNA substrate was resistant to exonuclease VII digestion (results not shown). The selfloading of the archaeal PCNA could be due to the presence of additional ion pairs and fewer hydrogen bonds at the subunit in terfaces ${ }^{31}$ In agreement with our data, it was previously shown that ATP hydrolysis by RF-C is not essential for either clamp loading onto DNA or the subsequent closing of the PCNA ring. ${ }^{25}$ It has also been suggested that the RF-C open/PCNA open state could be transformed to the RF-C closed/PCNA closed state by the consumption of very little energy. ${ }^{26}$ The existence of an equilibrium between open and closed PCNA could also explain the two bands we observe in the loading as say, with only one of them (the closed form) able to stimulate primer elongation (Figure 3). M13 DNA is highly structured, ${ }^{56}$ and protein binding may influence its structure. This view is supported by the data in Figure 3, where very different migration properties are observed in the presence of RF-C.

Our second major observation was that the PCNA loading efficiency was boosted by PabPol B. In the loading assay with $\mathrm{PabPol} \mathrm{B}$, we observed a signal similar to that observed with the PabRF-C complex, suggesting that once PabPol B interacts with PCNA, a very stable complex is formed on the DNA. This is similar to the situations previously described for the gp45 clamp with T4 DNA polymerase ${ }^{57}$ and for the $\mathrm{p} 125$ subunit of DNA polymerase $\delta .{ }^{58}$ The clamp is thus stabilized on the DNA by the DNA polymerase. 
The next question we addressed was what happens to the RF-C once the PCNA is loaded. We showed that in the presence of ATP, PabRF-C is released from the complex with PCNA and DNA; however, in the presence of the DNA polymerase, RF-C remains in the complex. Our data raise an intriguing question about the synthesis of DNA fragments of reduced size by PabPol B and the PabPol B-PCNA complex with PabRF-C. One hypothesis that can explain this phenomenon is non-specific DNA binding by the PabRF-C complex. Indeed, it has been shown that human RF-C displays significant binding to DNA templates. ${ }^{59-61}$ This strong and non-specific affinity is essentially due to the N-terminus of the p140 RF-C, which contains a DNA binding domain. ${ }^{62,63}$ However, this $\mathrm{N}$-terminal motif is lacking in the archaeal RF-C homologue. ${ }^{7}$ The lack of strong non-specific DNA bind ing is reinforced by our results showing that PabRF-C did not inhibit PabPol D DNA synthesis.

Previous studies have proposed that RF-C is interacting with PCNA when Pol $\delta$ binds to PCNA, suggesting that RF-C travels with Pol $\delta$ and PCNA. ${ }^{64}$ Also in Archaea, the clamploader is presumed to be released from the loaded PCNA after ATP hydrolysis. ${ }^{65}$ We show here that the picture could be different when DNA polymerases are present in the complex and that the RF-C could travel with the Pol and the PCNA during DNA synthesis. PabPols and PabRF-C exhibit the con sen sus Pip motif (QVGLGAWLKF and QVTLFDFI, respectively) at the C-terminus, and PabPol B increased the loading of the PCNA via this motif. Therefore, more than one partner, but only one DNA polymerase, can bind to PCNA. At the C-terminus of all Pyrococcus RF-C large subunits, there is a 56 amino acid peptide sequence just in front of the PIP box that contains 49 charged amino acids (Lys, Glu, or Arg). This sequence might be poorly structured and could be a flexible connector between the PIP box and the main part of the $P$. abyssi large subunit. This cluster contains ten residues upstream of the PIP box that are important for stable bind ing to the PCNA ${ }^{66}$. Moreover, an interaction between the subunit DP1 of PhoPol D and the large subunit of PhoRF-C has been 
detected in Pyrococcus horikoshii. ${ }^{67}$ Additional studies are required to elucidate the role of RF-C during archaeal DNA replication.

In the conditions tested, PabPol D is able to perform RNA primer extension and RNA strand displacement, whereas PabPol B is not. ${ }^{49}$ This suggests that $P a b P o l$ D could be required on both strands for elongation of the RNA primer and at the lagging stand to displace the downstream RNA primer. Here, we report a new DNA polymerase switching mechan is m by which PabPol B displaces PabPol D from PabPCNA on the DNA duplex. This switching could occur on both strands after RNA primer extension. On the other hand, PabPol B is unable to elongate a DNA primer if an RNA primer is located downstream up to 100 bases, ${ }^{49}$ and we show here that the PabPol B/PabPCNA complex was de-stabilized in the presence of an RNA primer and dNTPs. Considering that an archaeal Okazaki fragment length is up to

120 bases ${ }^{68}$ the RNA proximity would prevent the binding of PabPol B to PabPCNA during RNA primer elongation by $P a b P o l D$, suggesting that the polymerase switching could occur during the late phases. It is possible that $\mathrm{PabPol} \mathrm{D}$ could be required only for lagging strand synthesis, with polymerase switching at the leading strand leading to a very stable PabPol B/PabPCNA complex via the PabPol B PIP box motif.

\section{Acknowledgements}

This work was supported by a grant from the European Union (Project \# QLK3-CT-200202071 REPBIOTECH). The authors thank Audrey Le Goaziou for technical assistance. 


\section{MATERIALS AND METHODS}

\section{Chemicals and enzymes}

We used the $P$. abyssi GE5 strain. ${ }^{69}$ The genome of this organism was completely sequenced by Genoscope (Evry, France). E. coli DH5 $\alpha$ and HMS174(DE3) cells were purchased from Clontech Laboratories (Basingtoke, UK) and Novagen (Madison, WI, USA), respectively. [ $\gamma$ -

$\left.{ }^{32} \mathrm{P}\right] \mathrm{ATP}(5000 \mathrm{Ci} / \mathrm{mmol})$ was obtained from Amersham Biosciences (Saclay, France).

Polyacrylamide gel electrophoresis (PAGE) reagents were obtained from BioRad (Ivry sur Seine, France). All other chemicals were molecular biology reagents from Sigma-Aldrich (St. Lou is, MO, USA).

\section{Nucleic acid substrates}

Circular M13mp18 (M13ssc), either as single-stranded DNA or as primed single-stranded DNA, was obtained from Amersham Biosciences (Orsay, France). The primed substrate was obtained by annealing circular M13mp18 DNA to a DNA primer (5'-

ATTCGTAATCATGGTCATAGCTGTTTCCTG-3') or to an RNA primer (5' AUUCGUAAUCAUGGUCAUAGCUGUUUCCUG-3') at a 1:20 molar ratio, in $10 \mathrm{mM}$ Tris- $\mathrm{HCl} \mathrm{pH} 7.8,125 \mathrm{mM} \mathrm{NaCl}$ and $2.5 \mathrm{mM} \mathrm{MgCl}_{2}$, followed by heating at $90^{\circ} \mathrm{C}$ for $10 \mathrm{~min}$ and cooling to room temperature.

\section{Recombinant proteins}

The P. abyssi family B DNA polymerase ( $P a b P o l B)$ was the Isis ${ }^{\mathrm{TM}}$ DNA Polymerase commercialized by MP Biomedicals (Illkirch, France). P. abyssi family D DNA polymerase (PabPol D), PabRF-C, and PabPCNAwt were prepared as described earlier. ${ }^{7,48}$ The mutant PCNA PabPCNA(ded) was designed following results obtained with Pyrococcus furiosus. ${ }^{32}$ 
The amino acids E139, D143, and D147 were mutated to alanine by site-directed mutagenesis on the plasmid carrying the PabPCNAwt gene ${ }^{7}$ using the QuickChange ${ }^{\mathrm{TM}}$ Site-Directed Mutagenesis kit (Stratagene Europe, Amsterdam, The Netherlands). In order to obtain mutant PCNA deriv atives carrying a phosphorylation site (ph-PCNA and ph-PCNA(ded)), a consensus amino acid sequence with a serine phosphorylable by HMK was introduced at the

C-terminus of the protein. ${ }^{50} \mathrm{HMS} 174$ (DE3) cells were transformed with the plasmids carrying the PCNA genes, and the proteins were expressed and purified as described previously. ${ }^{7}$ Mutant PabPCNA was constructed by mutating leucine 211 to a cysteine. A mutant version of PabPol B, with a deletion of the C-terminal PIP-box ( $\Delta$ pip) was obtained using the same mutagenesis protocol. The codon corresponding to lysine 759, just upstream of the PIP-box, was replaced by a stop codon. Recombinant proteins were expressed and purified as described previously. ${ }^{48}$

\section{HPLC analysis}

A Bio-Tek Kontron 520 chromatograph was used with a 535 detector operating at a wavelength of $280 \mathrm{~nm}$. The flow cell was $8 \mu 1$ and a loop injector was used to inject $20 \mu 1$. The column was a Superdex 200 PC $(3.2 \mathrm{~mm}$ x $30 \mathrm{~cm})$ with a mean particle size of $13 \mu \mathrm{m}$ (Amersham Biosciences, Orsay, France). The buffer consisted of $50 \mathrm{mM}$ Tris- $\mathrm{HCl} \mathrm{pH} 7.5$, $1 \mathrm{mMDTT}$, and $0.15 \mathrm{M} \mathrm{NaCl}$, and the flow-rate was $40 \mu \mathrm{l} / \mathrm{min}$. Thyroglobulin (669 kDa), ferritin $(440 \mathrm{kDa})$, aldolase $(158 \mathrm{kDa})$, ribonuclease $\mathrm{A}(137 \mathrm{kDa})$, bovine serum albumin $(67 \mathrm{kDa})$, and ovalbumin (43 kDa) were used as molecular mass markers (Amersham Biosciences, Orsay, France). 


\section{Phosphorylation of ph-PCNA proteins}

The ph-PCNA proteins were incubated for $20 \mathrm{~min}$ at $37^{\circ} \mathrm{C}$ in a $15 \mu 1$ reaction containing 20 mM Tris- $\mathrm{HCl} \mathrm{pH}$ 7.5, $1 \mathrm{mM}$ DTT, $12 \mathrm{mM} \mathrm{MgCl}_{2}, 0.1 \mathrm{M} \mathrm{NaCl}, 12.5$ nmole $\left[\gamma^{32} \mathrm{P}\right]$ ATP, 1.15 $\mu \mathrm{g}$ of ph-PCNA or ph-PCNA(ded), and 2.25 Units of HMK (Sigma-Aldrich, St. Louis, MO, USA).

\section{Fluorescent labeling of $\operatorname{PabPCNA}(\mathrm{L211C})$}

PabPCNA(L211C) reacted with TAMRA (Molecular Probes, OR, USA) in 20 mM Tris-HCl pH 7.0, 0.1 mM EDTA, in an oxygen-free environment according to the manufacturer's instructions. The reaction was allowed to proceed for $2 \mathrm{~h}$ and then $1 \mathrm{mMDTT}$ was added. The labeled PCNA was purified sequentially on a $1 \mathrm{ml}$ Resource Q column (Amersham Biosciences, Orsay, France) with stepwise elution with $1 \mathrm{M} \mathrm{NaCl}$ buffer, followed by desalting on a HiPrep 26/10 column (Amersham Biosciences, Orsay, France). An 80\% yield of labeling was achieved.

\section{Visualization of ph-PCNA/DNA complexes (cross-linking reaction)}

The cross-linking reaction was carried out in $25 \mu 1$ of loading buffer $(20 \mathrm{mM}$ Hepes- $\mathrm{NaOH}$ pH 7.5, $2 \mathrm{mM}$ DTT, $3 \mathrm{mM} \mathrm{MgCl}$, $100 \mathrm{mM} \mathrm{NaCl}, 0.2 \mathrm{mg} / \mathrm{ml} \mathrm{BSA}$ ) containing $45 \mathrm{fmol}$ of the nucleic acid substrate. Proteins were sequentially added as follows: 1.5 pmol of PabRF-C, 1.6 pmol of PabPCNA, and 0.1 pmol of PabPol B or 0.4 pmol of PabPol D. ATP or ATP $\gamma$ S were added at $1 \mathrm{mM}$ final concentration and dNTPs at $0.4 \mathrm{mM}$. The reaction mixture was first incubated for $3 \mathrm{~min}$ at $65^{\circ} \mathrm{C}$, then $2.5 \mu$ l of the cross-linking reagent glutaraldehyde at $1 \%$ $(\mathrm{v} / \mathrm{v})$ were added. The mixture was further incubated for $10 \mathrm{~min}$ at $65^{\circ} \mathrm{C}$, and $5 \mu 1$ of loading buffer (20 mM Tris-HCl pH 8, 1 mM EDTA, 50\% glycerol and 0.07\% bromophenol blue) 
were added. The reaction mixture was then loaded onto a $0.8 \%$ agarose gel (TBE buffer contain ing $0.1 \%$ SDS) and electrophores is was performed for $1-2$ hours in the same buffer. The gel was then fixed with $10 \%$ trichloroacetic acid $(10 \mathrm{~min})$, rinsed two times in $10 \%$ acetic acid, 12\% methanol (10 min), dried under a vacuum and finally revealed by autoradiography. Fluorescence imaging was made by using a PabPCNA(L211C) labeled with tetramethylrhodamine and a M13ssc DNA primed with a 5'-fluorescein-labelled primer. Images were acquired on a Typhoon 9400 imager (Amersham Biosciences, Orsay, France).

\section{Interactions studies using biotin-labeled DNA template coupled to streptavidin beads} A 48-mer oligonucleotide (5'-GAGTGCACGTTGACTACCCGTCTTGAGGCAGAGTCCG ACATCTAGCTC-3') was annealed to a 5'3' biotinylated 75-mer oligonucleotide (5'-biotGAGCTAGATGTCGGACTCTGCCTCAAGA CGGGTAGTCAACGTGCACTCGAGGTCATTTTTTTTTTTTTTTTTTTTbiot-3') at equimolar ratio in a buffer containing $10 \mathrm{mM}$ Tris- $\mathrm{HCl} \mathrm{pH}$ 8.0, 1 mMEDTA, and $1 \mathrm{M} \mathrm{NaCl}$. Next, $300 \mathrm{fmol}$ of the biotinylated heteroduplex were incubated for $20 \mathrm{~min}$ with $20 \mu \mathrm{g}$ of streptavidin beads. The beads were washed 3 times with in $10 \mathrm{mM}$ Tris- $\mathrm{HCl} \mathrm{pH} 8.0,1 \mathrm{mM}$ EDTA, $1 \mathrm{M} \mathrm{NaCl}$. For one $25 \mu \mathrm{l}$ reaction, $20 \mu \mathrm{g}$ of beads loaded with the heteroduplex were resuspended in buffer (20 mM Hepes- $\mathrm{NaOH}$ pH 7.5, $2 \mathrm{mM}$ DTT, $3 \mathrm{mM} \mathrm{MgCl} 2,100 \mathrm{mM}$ $\mathrm{NaCl}$, and $0.2 \mathrm{mg} / \mathrm{ml} \mathrm{BSA}$ ). The reaction was then placed at $65^{\circ} \mathrm{C}$, and pre-heated proteins were add ed to the mixture, with or without washing between additions. The amounts used were $0.24,0.22,0.29$, and 0.22 pmol, respectively, of PabRF-C, PabPCNA, PabPol B, or PabPol D; ATP or ATP $\gamma \mathrm{S}$ was added to a final concentration of $1 \mathrm{mM}$. The reaction was incubated for $3 \mathrm{~min}$, and then the beads were washed three times with $1 \mathrm{ml}$ of PBS, resuspended in loading buffer, and subjected to SDS-PAGE. After separation, proteins were transferred to nitrocellulose membranes. The blots were saturated with blocking buffer 
contain ing 5\% (w/v) skimmed milk in TBS-T (Tris-buffered saline: $10 \mathrm{mM}$ Tris- $\mathrm{HCl} \mathrm{pH} 7.5$, $150 \mathrm{mM} \mathrm{NaCl}, 0.05 \%(\mathrm{v} / \mathrm{v})$ Tween 20) for $30 \mathrm{~min}$, then incubated for $2 \mathrm{~h}$ at room temperature with specific rabbit polyclonal antibodies directed against replic ation proteins (Eurogentec, Seraing, Belgium).

The membranes were washed three times with TBS-T, and then incubated for two hours with a 1:5,000 dilution of horseradish peroxidase-conjugated anti-rabbit antibody or 1:10,000 dilution of horseradish peroxidase-linked anti-mouse IgG in $2 \%(\mathrm{w} / \mathrm{v})$ skimmed milk in TBST. The membranes were washed three times in TBS-T, and the secondary antibody was detected using enhanced chemiluminescence solution (SuperSignal ${ }^{\circledR}$ West Pico Chemilumin escence Substrate, Pierce, Rockford, IL, USA) according to the manufacturer's instructions.

\section{Primer extension assays}

The primer extension reactions ( $25 \mu 1$ total volume) were incubated for $20 \mathrm{~min}$ at $65^{\circ} \mathrm{C}$. Each reaction contained either $1.1 \mathrm{pmol}$ of $\mathrm{PabPol} \mathrm{B}$ in $50 \mathrm{mM}$ Tris- $\mathrm{HCl} \mathrm{pH} 8.0,2 \mathrm{mM} \mathrm{MgCl}_{2}, 1$ mM DTT, $10 \mathrm{mM} \mathrm{KCl}, 0.4 \mathrm{mg} / \mathrm{ml}$ BSA or else contained 2.3 pmol of PabPol D in $20 \mathrm{mM}$ Bis-Tris pH 6.8, $10 \mathrm{mM} \mathrm{MgCl} 2,1 \mathrm{mM}$ DTT, $0.4 \mathrm{mg} / \mathrm{ml} \mathrm{BS} \mathrm{A.} \mathrm{Also} \mathrm{included} \mathrm{were} 0.2 \mathrm{mM}$ dNTPs, $3 \mu \mathrm{M}$ of $\left[\alpha_{-}{ }^{32} \mathrm{P}\right] \mathrm{dATP}, 57 \mathrm{fmol}$ of primed M13ssc DNA, 0.6 pmol of PCNA, 0.25 to 2.5 pmol of RF-C, and $0.5 \mathrm{mM}$ of ATP or ATP $\gamma$ S. Loading buffer ( $3 \mu 1$ containing $0.5 \mathrm{M}$ $\mathrm{NaOH}, 10 \mathrm{mM}$ EDTA, $25 \%$ Ficoll 400 , and $0.25 \%$ bromophenol blue) was then added to the reaction mixture and products were resolved on $1.2 \%$ denaturing agarose gels at low temperature in a TAE $0.05 \mathrm{x}$ buffer containing $15 \mathrm{mM} \mathrm{NaOH}$ and $0.5 \mathrm{mM}$ EDTA. The gels were dried at room temperature and subjected to phosphorimaging analysis. A $\lambda$ Hind III

digest was labeled by incorporation of $\left[\alpha_{-}{ }^{32} \mathrm{P}\right] \mathrm{dATP}$ with Klenow fragments and used as molecu lar weight markers. 


\section{FIGURE LEGENDS}

Figure 1: Loading of PabPCNA onto a short DNA template. Pull-down experiments were performed as described in Materials and Methods with $300 \mathrm{fmol}$ of the primed (sspDNA) or non-primed (ssDNA) 75-mer oligonucleotide immobilized on biotin beads. (a) Incubations were performed at $65^{\circ} \mathrm{C}$ for $3 \mathrm{~min}$, in $25 \mu 1$ of $20 \mathrm{mM}$ Hepes- $\mathrm{NaOH}$ pH 7.5, $2 \mathrm{mM}$ DTT, 3 $\mathrm{mM} \mathrm{MgCl} 2,100 \mathrm{mM} \mathrm{NaCl}, 0.2 \mathrm{mg} / \mathrm{ml} \mathrm{BSA}$, varying amounts of PabPCNA, and $20 \mu \mathrm{g}$ of beads carrying the heteroduplex. The products were analyzed on a 7.5\% SDS-PAGE gel by Western blot with PabPCNA antibodies. PabPCNA was 0.06 (lanes 2 and 6), 0.6 (lanes 1, 3 and 7), 1.2 (lanes 4 and 8) or 2.4 (lanes 5 and 9) pmol. 'Input' is a positive control with 0.12 pmol of PabPCNA. (b) Incubations were performed with 0.6 pmol of PabPCNA and 3 fmol of competitor DNA (the primed non-biotinylated 75-mer). The incubation temperature is indicated at the top of the panel. Semi-quantitative densitometry analysis was performed on the gels. The highest band intensity for each experiment was considered to be the $100 \%$ value. These values are indicated underneath each panel. The molecular weight markers (M) were the ECL DualVue Western Blotting Markers from Amersham (Uppsala, Sweden).

Figure 2: Loading of PabPCNA onto primed M13ssc DNA: effects of PabRF-C and PabPol B. (a) The $25 \mu \mathrm{l}$ reaction mixtures contained, in addition to buffer (see Materials and Methods), 45 fmol of primed M13ssc DNA (all reactions except lane 1); 1.8 pmol of $\left[{ }^{32} \mathrm{P}\right]$ PabPCNA (wild-type, wt, or mutant, ded); 1.2 pmol of PabRF-C; 1 mM ATP or ATP $\gamma$; and $0.1 \mathrm{pmol}$ of $\mathrm{PabPol} \mathrm{B}$ as indicated for each lane. Reactions were incubated at $65^{\circ} \mathrm{C}$ for 3 min, and PCNA loading was measured by the cross-linking technique described in Materials and Methods. Lane 1 is a negative control lacking M13ssc DNA. (b) Co-localization of DNA and PabPCNA on agarose gels. The reactions contained DNA (1) or DNA + PCNA (2). The excitation wavelength was $488 \mathrm{~nm}$ for fluorescein-labeled primed M13ssc DNA and $532 \mathrm{~nm}$ 
for rhodamine-labeled PabPCNA. On the right, the two images were superimposed, showing a yellow co-localization signal. The low inten sity band for reaction 2 at $532 \mathrm{~nm}$ is due to some fluorescein signal at this wavelength (c) Semi-quantitative densitometry an alysis of gels from six different experiments performed as described in Figure 2(a); the bands corresponding to conditions in lanes 2, 3, 4, and 5, respectively, in Figure 2(a), were quantified and the intensity of the ATP $\gamma \mathrm{S}$ band (lane 5) was considered to be the $100 \%$ value. Error bars indicate the confidence level for the difference between the means ( $\left.\bar{X} \pm t_{\alpha / 2} S_{\bar{X}}\right)$, where $\alpha$ is the significance level used to compare the confidence level $(0.05)$ and $t_{\alpha / 2}$, the critical value from the $\mathrm{t}$ table with $\mathrm{n}-1$ degrees of freedom.

(d) Superdex 200 PC chromatography of PabPCNAwt and PabPCNA(ded); conditions are described in Materials and Methods and the elution profiles correspond to the homotrimer PabPCNAwt and the monomer PabPCNA(ded), respectively

Figure 3: PabPol B-stimulated PabPCNA loading: a functional complex forms on a primed DNA template. (a) The reaction mixtures are as described in Figure 2(a), including 1.8 pmol of $\left[{ }^{32} \mathrm{P}\right] \mathrm{PabPCNA}$ in all reactions; either non-primed (M13ssc) or primed (pM13ssc) M13 single-stranded DNA; 1.2 pmol of PabRF-C (lanes 3-5 and 7-9); 0.1 pmol of PabPol B (lanes 10-13), $1 \mathrm{mM}$ ATP or ATPYS; and $0.4 \mathrm{mM}$ dNTPs as indicated. PCNA loading was measured by cross-linking. (b) The reaction mixtures contained 45 fmol of DNA- or RNA-primed M13ssc DNA, as indicated at the bottom of the panel, and 1.8 pmol of $\left[{ }^{32} \mathrm{P}\right] \mathrm{PabPCNA}$. PabRF-C was added with ATP $\gamma \mathrm{S}$ and the quantities of PabRF-C, PabPol B (or the PIP-boxdeleted mutant PabPol B( $\Delta$ pip)), dNTPs, and ATP $\gamma$ S are indicated in the legend to panel 3(a), above. 
Figure 4: Primer elongation studies of $P$. abyssi DNA polymerases. The elongation reactions (see Materials and Methods) contained 1 pmol of PabPol B or 2.3 pmol of PabPol D, 56 fmol of primed M13ssc DNA, 2.4 pmol of PabPCNA (wild-type, wt, or mutant, ded), 2 pmol of PabRF-C, and $0.5 \mathrm{mM}$ of ATP or ATP $\gamma \mathrm{S}$. Reactions were incubated at $65^{\circ} \mathrm{C}$ for $20 \mathrm{~min}$, and products were resolved on $1.2 \%$ denaturing agarose gels and visualized by phosphoimaging analysis. Markers (M1 and M2) are Hind III digests of phage $\lambda$ DNA labeled by incorporation of $\left[{ }^{32} \mathrm{P}\right] \mathrm{dATP}$ with the Klenow fragment. (a) Effect of wild-type and mutant PabPCNA on PabPol B; 'ph-' indicates that the PCNA has a protein kinase consensus amino acid sequence at the C-terminus. (b) Effect of PabRF-C and varying conditions on PabPol B (lanes 1-8) or PabPol D (lanes 9-16). (c) PabRF-C was added at different times during the incubation, as indicated above the panel.

Figure 5: The stability of the PabPCNA/PabRF-C complex is modulated by ATP hydrolysis. Pull-down experiments were performed as described in Figure 1, and the products were analyzed by Western blot with antibodies to PabPCNA (a) or to the small subunit of PabRFC (b). Lanes 1 and 2, controls with biotin immobilized on the beads; lanes 3-6, $300 \mathrm{fmol}$ of primed 75-mer oligonucleotide were immobilized on $20 \mu \mathrm{g}$ of streptavidin beads as described in Materials and Methods. Experiments were as follows. Lane 1, 2.4 pmol of PabPCNA; lane 2, 2 pmol of PabRF-C; lane 3, 2.4 pmol of PabPCNA; lane 4, 2 pmol of PabRF-C; lane 5, 2.4 pmol of PabPCNA, 2 pmol of PabRF-C, and 1 mM ATP $\gamma$; lane 6, 2.4 pmol of PabPCNA, 2 pmol of PabRF-C, and $1 \mathrm{mM}$ ATP.

Figure 6: Physical interaction of PabPCNA with DNA and proteins. Experiments were performed as described in Figure 1 with the biotinylated primed 75-mer oligonucleotide immobilized on streptavidin beads, except that 0.5 pmol of the indicated proteins were added. 
When RF-C was present, $1 \mathrm{mM}$ ATP was added. Products were analyzed by $7.5 \%$ SDS-

PAGE. (a) Western blot using antibodies to PabPCNA, the PabRF-C small subunit, $P a b$ Pol $\mathrm{B}$, or the PabPol D small subunit, as indicated to the right of the panels. The positive con trol lane is labeled 'Input' with 0.01 pmol of PabPCNA, 0.15 pmol of PabRF-C, 0.06 pmol of PabPol B, or 0.04 pmol of PabPol D, respectively. (b) Semi-quantitative an alysis of the data in Figure 6(a); for each gel, the highest band intensity was considered to be the $100 \%$ value. 


\section{REFERENCES}

1. Forterre, P., Filée, J. \& Myllykallio, H. (2004). Origin and evolution of DNA and DNA replication machineries. In The Genetic Code and the Orig in of Life (de Pouplana, L. R., ed.), pp. 145-168. Kluwer Academic/Plenum Publishers, New York.

2. Kelman, Z. \& O'Donnell, M. (1994). DNA replication: enzymology and mechanisms. Curr. Opin. Genet. Develop. 4, 185-195.

3. Toueille, M. \& Hübscher, U. (2004). Regulation of the DNA replication fork: a way to fight genomic instability. Chromosoma 113, 113-125.

4. Kornberg, A. \& Baker, T. A. (1992). Regulation of chromosomal replication and cell division. In DNA replication (Kornberg, A. \& Baker, T. A., eds.), pp. 731-769. Freeman, New York.

5. Mossi, R. \& Hübscher, U. (1998). Clamping down on clamps and clamp loaders - The eukaryotic replication factor C. Eur. J. Biochem. 254, 209-216.

6. Bertram, J. G., Bloom, L. B., Hingorani, M. M., Beechem, J. M., O'Donnell, M. \& Goodman, M. F. (2000). Molecular mechanism and energetics of clamp assembly in Escherichia coli - The role of ATP hydrolysis when $\gamma$ complex loads $\beta$ on DNA. J. Biol. Chem. 275, 28413-28420.

7. Henneke, G., Gueguen, Y., Flament, D., Azam, P., Querellou, J., Dietrich, J., Hübscher, U. \& Raffin, J. P. (2002). Replication Factor C from the hyperthermophilic archaeon Pyrococcus abyssi does not need ATP hydrolysis for clamp-loading and contains a functionally conserved RFC PCNA-binding domain. J. Mol. Biol. 323, 795810.

8. Johnson, A. \& O'Donnell, M. (2005). Cellular DNA replicases: components and dynamics at the replication fork. Annu. Rev. Biochem. 74, 283-315. 
9. O'Donnell, M., Jeruzalmi, D. \& Kuriyan, J. (2001). Clamp loader structure predicts the architecture of DNA polymerase III holoenzyme and RFC. Curr. Biol. 11, R935R946.

10. Onrust, R., Finkelstein, J., Naktinis, V., Turner, J., Fang, L. H. \& Odonnell, M. (1995). Assembly of a chromosomal replication machine: Two DNA polymerases, a clamp loader, and sliding clamps in one holoenzyme particle .1. Organization of the clamps loader. J. Biol. Chem. 270, 13348-13357.

11. Kong, X. P., Onrust, R., O'Donnell, M. \& Kuriyan, J. (1992). Three-dimensional structure of the $\beta$ subunit of E. coli DNA polymerase III holoenzyme: a sliding DNA clamp. Cell 69, 425-437.

12. Jeru zalmi, D., O'Donnell, M. \& Kuriyan, J. (2001). Crystal structure of the processivity clamp loader gamma (gamma) complex of E-coli DNA polymerase III. Cell 106, 429-441.

13. Pietroni, P., Young, M. C., Latham, G. J. \& Vonhippel, P. H. (1997). Structural analyses of gp 45 sliding clamp interactions during assembly of the bacteriophage T4 DNA polymerase holoenzyme .I. Conformational changes within the gp44/62-gp45ATP complex during clamp loading. J. Biol. Chem. 272, 31666-31676.

14. Latham, G. J., Bacheller, D. J., Pietroni, P. \& von Hippel, P. H. (1997). Structural Analyses of gp45 Sliding Clamp Interactions during Assembly of the Bacteriophage T4 DNA Polymerase Holoenzyme. II. The gp44/62 Clamp loader interacts with a single defined face of the sliding clamp ring. J. Biol. Chem. 272, 31677-31684.

15. Latham, G. J., Bacheller, D. J., Pietroni, P. \& Vonhippel, P. H. (1997). Structural analyses of gp45 sliding clamp interactions during assembly of the bacteriophage T4 DNA polymerase holoenzyme .III. The gp43 DNA polymerase binds to the same face of the sliding clamp as the clamp loader. J. Biol. Chem. 272, 31685-31692. 
16. Ishmael, F. T., Trakselis, M. A. \& Benkovic, S. J. (2003). Protein-protein interactions in the bacteriophage T4 replisome - The leading strand holoenzyme is physically linked to the lagging strand holoenzyme and the primosome. J. Biol. Chem. 278, 31453152 .

17. Allers, T. \& Mevarech, M. (2005). Archaeal genetics - The third way. Nature Rev. Genet. 6, 58-73.

18. Henneke, G., Raffin, J. P., Ferrari, E., Jónsson, Z. O., Dietrich, J. \& Hübscher, U. (2000). The PCNA from Thermococcus fumicolans functionally interacts with DNA polymerase delta. Biochem. Biophys. Res. Commun. 276, 600-606.

19. Ishino, Y., Tsurimoto, T., Ishino, S. \& Cann, I. K. (2001). Functional interactions of an archaeal sliding clamp with mammalian clamp loader and DNA polymerase $\delta$. Genes Cells 6, 699-706.

20. Yao, N. Y., Coyell, L., Zhang, D., Georgescu, R., Finkelstein, J., Coman, M. M., Hingorani, M. M. \& O'Donnell, M. (2003). Replication Factor C clamp loader subunit arrangement within the circular pentamer and its attachment points to PCNA. J. Biol. Chem. 278, 50744-50753.

21. Cann, I. K. O., Ishino, S., Hayashi, I., Komori, K., Toh, H., Morikawa, K. \& Ishino, Y. (1999). Functional interactions of a homolog of proliferating cell nuclear antigen with DNA polymerases in Archaea. J. Bacteriol. 181, 6591-6599.

22. Pisani, F. M., De Felice, M., Carpentieri, F. \& Rossi, M. (2000). Biochemical characterization of a clamp-loader complex homologous to eukaryotic replication factor C from the hyperthermophilic archaeon Sulfolobus solfataricus. J. Mol. Biol. 301, 61-73. 
23. Seybert, A., Scott, D. J., Scaife, S., Singleton, M. R. \& Wigley, D. B. (2002).

Biochemical characterisation of the clamp/clamp loader proteins from the euryarchaeon Archaeoglobus fulgidus. Nucl. Acids Res. 30, 4329-4338.

24. Chen, Y. H., Kocherginskaya, S. A., Lin, Y., Sriratana, B., Lagunas, A. M., Robbins, J. B., Mackie, R. I. \& Cann, I. K. O. (2005). Biochemical and mutational analyses of a unique clamp loader complex in the archaeon Methanosarcina acetivorans. J. Biol. Chem. 280, 41852-41863.

25. Miyata, T., Oyama, T., Mayanagi, K., Ishino, S., Ishino, Y. \& Morikawa, K. (2004). The clamp-loading complex for processive DNA replication. Nature Struct. Mol. Biol. 11, 632-636.

26. Miyata, T., Suzuki, H., Oyama, T., Mayanagi, K., Ishino, Y. \& Morikawa, K. (2005). Open clamp structure in the clamp-loading complex visualized by electron microscopic image analysis. Proc. Natl. Acad. Sci. USA 102, 13795-13800.

27. Lee, I., Lokanath, N. K., Min, K., Ha, S. C., Kim, D. Y. \& Kim, K. K. (2002). Cloning, purification, crystallization and preliminary X-ray studies of RFC boxes II-VIII of replication factor C from Methanococcus jannaschii. Acta Cryst. Ser. D 58, 519-521.

28. Bowman, G. D. (2004). Structural analysis of a eukaryotic sliding DNA clamp-clamp loader complex. Nature 429, 724-730.

29. Kitabayashi, M., Nishiya, Y., Esaka, M., Itakura, M. \& Imanaka, T. (2002). Gene cloning and polymerase chain reaction with proliferating cell nuclear antigen from Thermococcus kodakaraensis KOD1. Biosci. Biotechnol. Biochem. 66, 2194-2200.

30. Daimon, K., Kawarabayasi, Y., Kikuchi, H., Sako, Y. \& Ishino, Y. (2002). Three Proliferating Cell Nuclear Antigen-Like Proteins Found in the Hyperthermophilic 
Archaeon Aeropyrum pernix: Interactions with the Two DNA Polymerases. $J$.

Bacteriol. 184, 687-694.

31. Matsumiya, S., Ishino, Y. \& Morikawa, K. (2001). Crystal structure of an archaeal DNA sliding clamp: Proliferating Cell Nuclear Antigen from Pyrococcus furiosus. Protein Sci. 10, 17-23.

32. Matsumiya, S., Ishino, S., Ishino, Y. \& Morikawa, K. (2003). Intermolecular ion pairs maintain the toroidal structure of Pyrococcus furiosus PCNA. Protein Sci. 12, 823831.

33. De Felice, M., Sensen, C. W., Charlebois, R. L., Rossi, M. \& Pisani, F. M. (1999). Two DNA polymerase sliding clamps from the thermophilic archaeon Sulfolobus solfataricus. J. Mol. Biol. 291, 47-57.

34. Dionne, I., Nookala, R. K., Jackson, S. P., Doherty, A. J. \& Bell, S. D. (2003). A heterotrimeric PCNA in the hyperthermophilic archaeon Sulfolobus solfataricus. Mol. Cell 11, 275-282.

35. Maga, G. \& Hübscher, U. (2003). Proliferating cell nuclear antigen (PCNA): a dancer with many partners. J. Cell Sci. 116, 3051-3060.

36. Naktinis, V., Turner, J. \& O'Donnell, M. (1996). A molecular switch in a replication machine defined by an internal competition for protein rings. Cell 84, 137-145.

37. Lopez de Saro, F., Georgescu, R. E., Leu, F. \& O'Donnell, M. (2004). Protein trafficking on sliding clamps. Philos. Trans. R. Soc. Lond. Ser. B Biol. Sci. 359, 25-30.

38. Levin, D. S., Bai, W., Yao, N., Odonnell, M. \& Tomkin son, A. E. (1997). An interaction between DNA ligase I and proliferating cell nuclear antigen: Implications for Okazaki fragment synthesis and joining. Proc. Natl. Acad. Sci. USA 94, 1286312868. 
39. Plosky, B. S. \& Woodgate, R. (2004). Switching from high-fidelity replicases to lowfidelity lesion-bypass polymerases. Curr. Opin. Genet. Develop. 14, 113-119.

40. Friedberg, E. C., Lehmann, A. R. \& Fuchs, R. P. P. (2005). Trading Places: How Do DNA Polymerases Switch during Translesion DNA Synthesis? Mol. Cell 18, 499-505.

41. Lehmann, A. R. (2006). Translesion synthesis in mammalian cells. Exp. Cell Res. 312, 2673-2676.

42. Carson, D. R. \& Christman, M. F. (2001). Evidence that replication fork components catalyze establishment of cohesion between sister chromatids. Proc. Natl. Acad. Sci. USA 98, 8270-8275.

43. Cann, I. K. O., Ishino, S., Nomura, N., Sako, Y. \& Ishino, Y. (1999). Two family B DNA polymerases from Aeropyrum pernix, an aerobic hyperthermophilic crenarchaeote. J. Bacteriol. 181, 5984-5992.

44. Iwai, T., Kurosawa, N., Itoh, Y. H., Kimura, N. \& Horiuchi, T. (2000). Sequence analysis of three family B DNA polymerases from the thermoacidophilic crenarchaeon Sulfurisphaera ohwakuensis. DNA Res. 7, 243-251.

45. Cann, I. K. O., Komori, K., Toh, H., Kanai, S. \& Ishino, Y. (1998). A heterodimeric DNA polymerase: Evidence that members of Euryarchaeota possess a distinct DNA polymerase. Proc. Natl. Acad. Sci. USA 95, 14250-14255.

46. Ishino, Y. \& Cann, I. K. O. (1998). The euryarchaeotes, a subdomain of Archaea, survive on a single DNA polymerase: Fact or farce? Genes Genet. Syst. 73, 323-336.

47. Shen, Y., Musti, K., Hiramoto, M., Kikuchi, H., Kawarabayashi, Y. \& Matsui, I. (2001). Invariant Asp1122 and Asp1124 are essential residues for polymerization catalysis of family D DNA polymerase from Pyrococcus horikoshii. J. Biol. Chem. 276, 27376-27383. 
48. Gueguen, Y., Rolland, J. L., Lecompte, O., Azam, P., Le Romancer, G., Flament, D., Raffin, J. P. \& Dietrich, J. (2001). Characterization of two DNA polymerases from the hyperthermophilic euryarchaeon Pyrococcus abyssi. Eur. J. Biochem. 268, 5961-5969.

49. Henneke, G., Flament, D., Hübscher, U., Querellou, J. \& Raffin, J. P. (2005). The Hyperthermophilic Euryarchaeota Pyrococcus abyssi Likely Requires the Two DNA Polymerases D and B for DNA Replication. J. Mol. Biol. 350, 53-64.

50. Podust, L. M., Podust, V. N., Sogo, J. M. \& Hübscher, U. (1995). Mammalian DNA polymerase auxiliary proteins: Analysis of replication factor C-catalyzed proliferating cell nuclear antigen loading onto circular double-stranded DNA. Mol. Cell Biol. 15, 3072-3081.

51. Warbrick, E. (1998). PCNA binding through a conserved motif. Bioessays 20, $195-$ 199.

52. Waga, S. \& Stillman, B. (1998). The DNA replication fork in eukaryotic cells. Annu. Rev. Biochem. 67, 721-751.

53. Hübscher, U., Maga, G. \& Spadari, S. (2002). Eukaryotic DNA polymerases. Annu. Rev. Biochem. 71, 133-163.

54. Shcherbakova, P. V., Bebenek, K. \& Kunkel, T. A. (2003). Functions of eukaryotic DNA polymerases. Sci. Aging Knowl. Environ. 2003, RE3.

55. Fukui, T., Yamauchi, K., Muroya, T., Akiyama, M., Maki, H., Sugino, A. \& Waga, S. (2004). Dis tinct roles of DNA polymerases $\delta$ and $\varepsilon$ at the replication fork in Xenopus egg extracts. Genes Cells 9, 179-191.

56. Reckman, B., Grosse, F., Urbanke, C., Frank, R., Blöcker, H. \& Krauss, G. (1985). Analysis of secondary structures in M13mp18(+) single-stranded DNA by the pausing of DNA polymerase $\alpha$. Eur. J. Biochem. 152, 633-643. 
57. Yao, N., Turner, J., Kelman, Z., Stuckenberg, P. T., Dean, F. B., Shechter, D., Pan, Z. Q., Hurwitz, J. \& O'Donnell, M. (1996). Clamp-loading, unloading and intrinsic stability of the PCNA, beta and gp45 sliding clamps of human, E. coli and T4 replicases. Genes Cells 1, 101-113.

58. Zhang, P., Mo, J. Y., Perez, A., Leon, A., Liu, L., Mazloum, N., Xu, H. \& Lee, M. (1999). Direct in teraction of proliferating cell nuclear antigen with the p125 catalytic subunit of mammalian DNA polymerase $\delta$. J. Biol. Chem. 274, 26647-26653.

59. Lee, S. \& Hurwitz, J. (1990). Mechanism of Elongation of Primed DNA by DNA Polymerase $\delta$, Proliferating Cell Nuclear Antigen, and Activator 1. Proc. Natl. Acad. Sci. USA 87, 5672-5676.

60. Tsurimoto, T. \& Stillman, B. (1991). Replication factors required for SV40 DNA replication in vitro. I. DNA structure-specific recognition of a primer-template junction by eukaryotic DNA polymerases and their accessory proteins. J. Biol. Chem. 266, 1950-1960.

61. Keller, R. C., Mossi, R., Maga, G., Wellinger, R. E., Hübscher, U. \& Sogo, J. M. (1999). Electron microscopic analys is reveals that replication factor $\mathrm{C}$ is sequestered by single-stranded DNA. Nucl. Acids Res. 27, 3433-3437.

62. Burbelo, P. D., Utani, A., Pan, Z. Q. \& Yamada, Y. (1993). Cloning of the large subunit of activator 1 (replication factor C) reveals homology with bacterial DNA ligases. Proc. Natl. Acad. Sci. USA 90, 11543-11547.

63. Fotedar, R., Mossi, R., Fitzgerald, P., Rousselle, T., Maga, G., Brickner, H., Messier, H., Khastilba, S. \& Hübscher, U. (1996). A conserved domain of the large subunit of replication factor $\mathrm{C}$ binds PCNA and acts like a dominant negative inhibitor of DNA replication in mammalian cells. EMBO J. 15, 4423-4433. 
64. Yuzhakov, A., Kelman, Z., Hurwitz, J. \& O'Donnell, M. (1999). Multiple competition reactions for RPA order the assembly of the DNA polymerase $\delta$ holoenzyme. EMBO J. 18, 6189-6199.

65. Barry, E. R. \& Bell, S. D. (2006). DNA Replication in the Archaea. Microbiol. Mol. Biol. Rev. 70, 876-887.

66. Nishida, H., Ishino, S., Miyata, T., Morikawa, K. \& Ishino, Y. (2005). Identification of the critical region in replication factor $\mathrm{C}$ from Pyrococcus furiosus for the stable complex formation with proliferating cell nuclear antigen and DNA. Genes Genet. Syst. 80, 83-93.

67. Tang, X. F., Shen, Y., Matsui, E. \& Matsui, I. (2004). Domain Topology of the DNA Polymerase D Complex from a Hyperthermophilic Archaeon Pyrococcus horikoshii. Biochemistry USA 43, 11818-11827.

68. Matsun aga, F., Norais, C., Forterre, P. \& Myllykallio, H. (2003). Identification of short 'eukaryotic' Okazaki fragments synthesized from a prokaryotic replication origin. EMBO Rep. 4, 1-5.

69. Erauso, G., Reysenbach, A. L., Godfroy, A., Meunier, J. R., Crump, B., Partensky, F., Baross, J. A., Marteinsson, V., Barbier, G., Pace, N. R. \& Prieur, D. (1993). Pyrococcus abyssi sp. nov., a new hyperthermophilic archaeon isolated from a deepsea hydrothermal vent. Arch. Microbiol. 160, 338-349. 
(a)

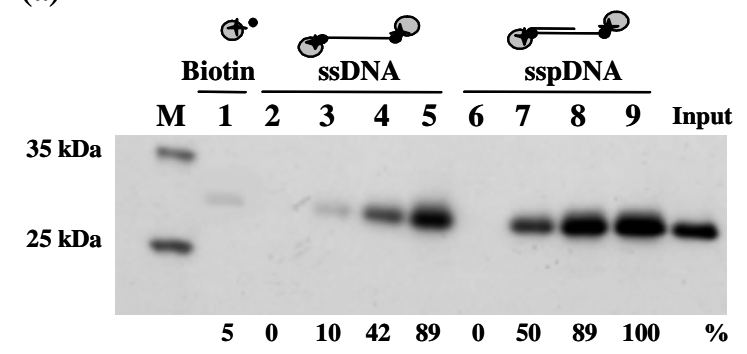

(b)

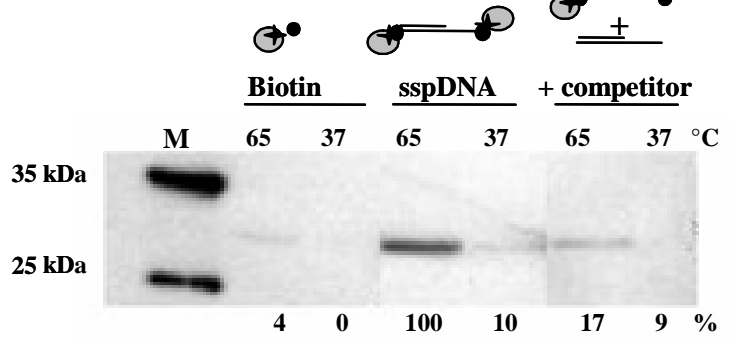


(a)

$\begin{array}{lllllllllllll}1 & 2 & 3 & 4 & 5 & 6 & 7 & 8 & 9 & 10 & 11 & 12 & 13\end{array}$

PabPCNAwt $+++++---_{+}++++$

PabPCNA(ded) - $-\quad--++++--$

PabRF-C --+++++++++

ATP

PabPol B

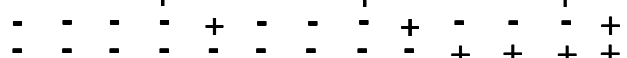

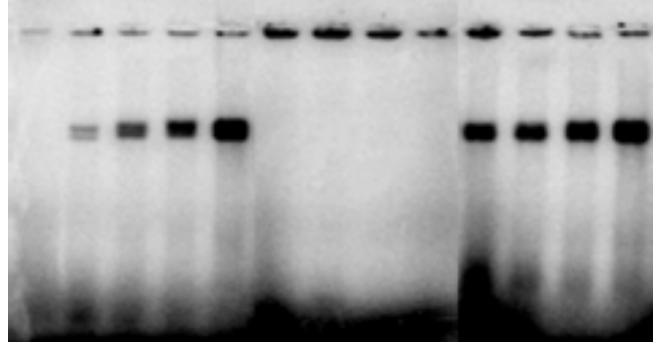

(d)

(c) (b)
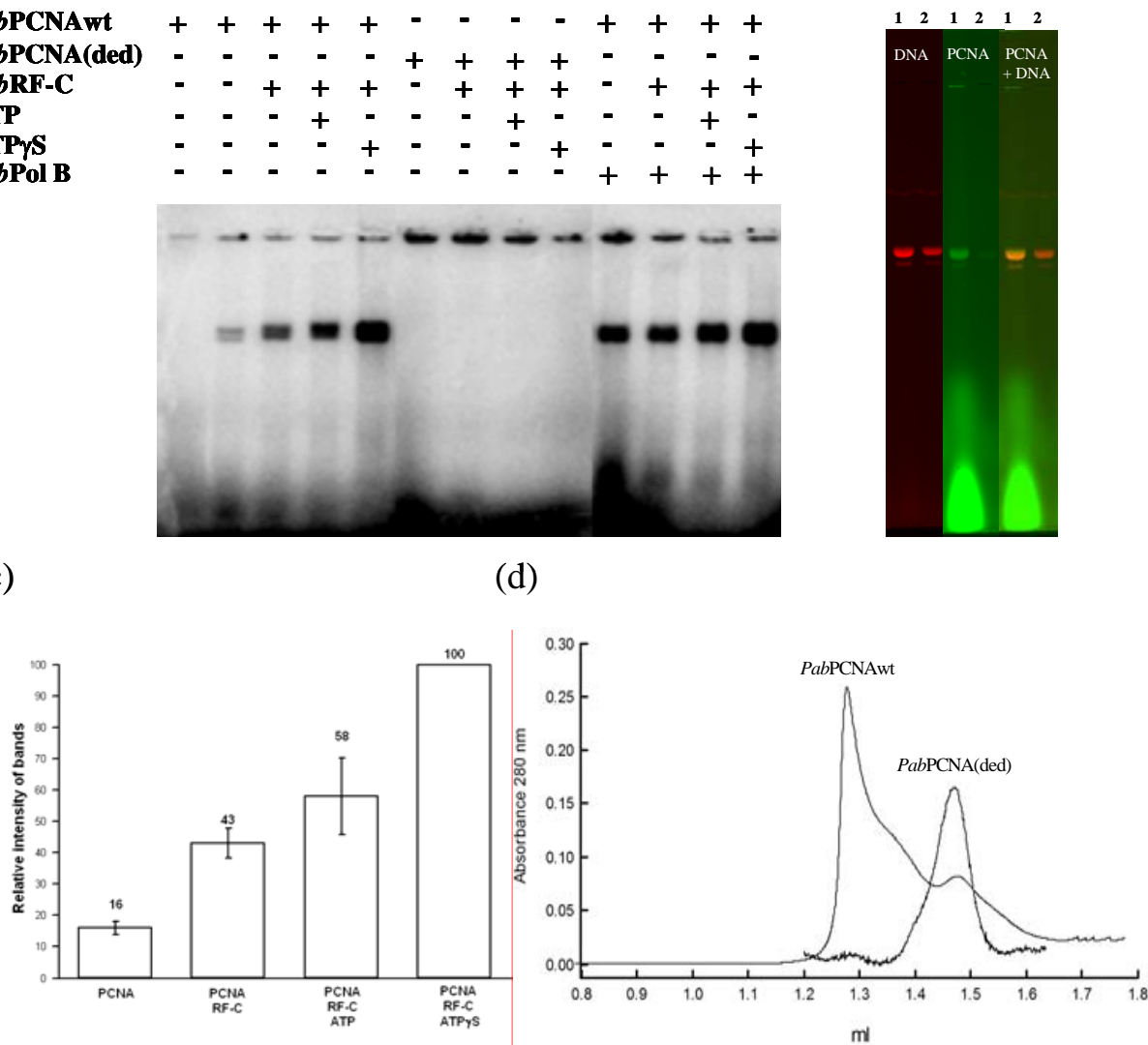
Figure

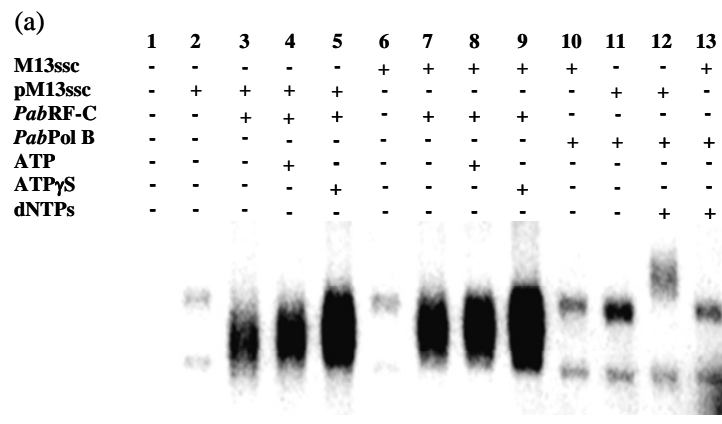

$\begin{array}{llllllllllll}2 & 3 & 4 & 5 & 6 & 7 & 8 & 9 & 10 & 11 & 12 & 13\end{array}$

pM13ssc

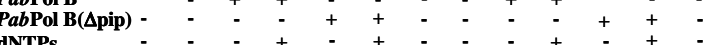

RF-C

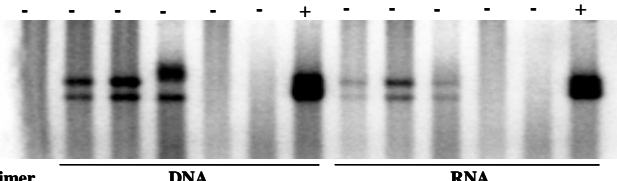


(a)

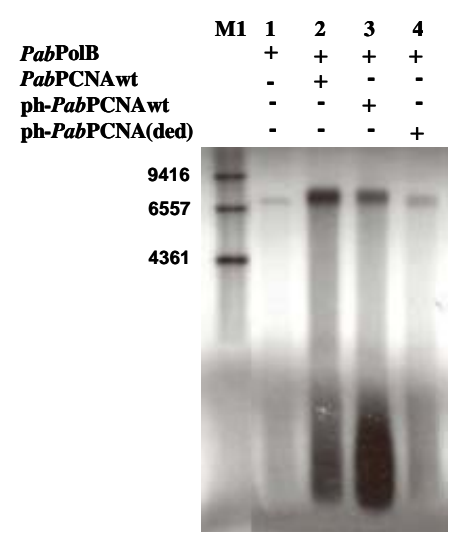

(b)

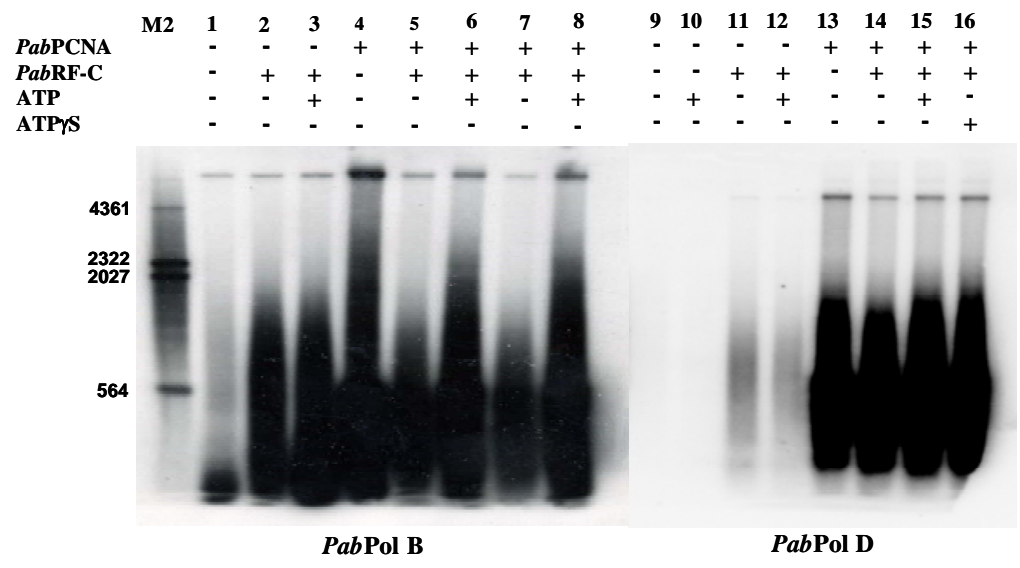

(c)

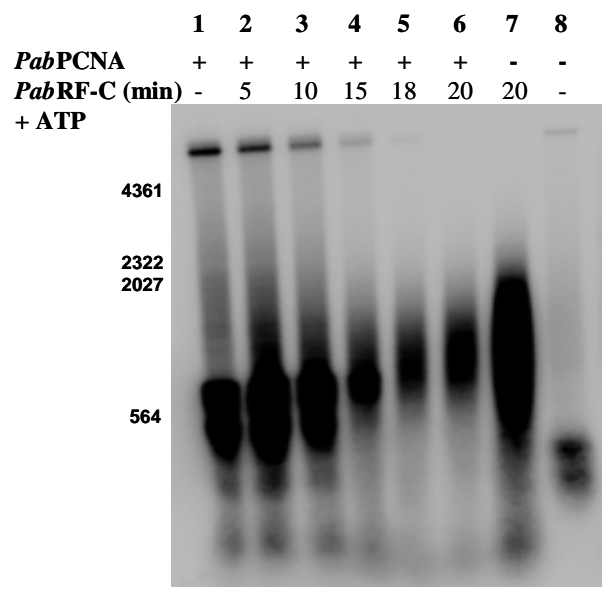


Figure

(a)

$35 \mathrm{kDa}=$

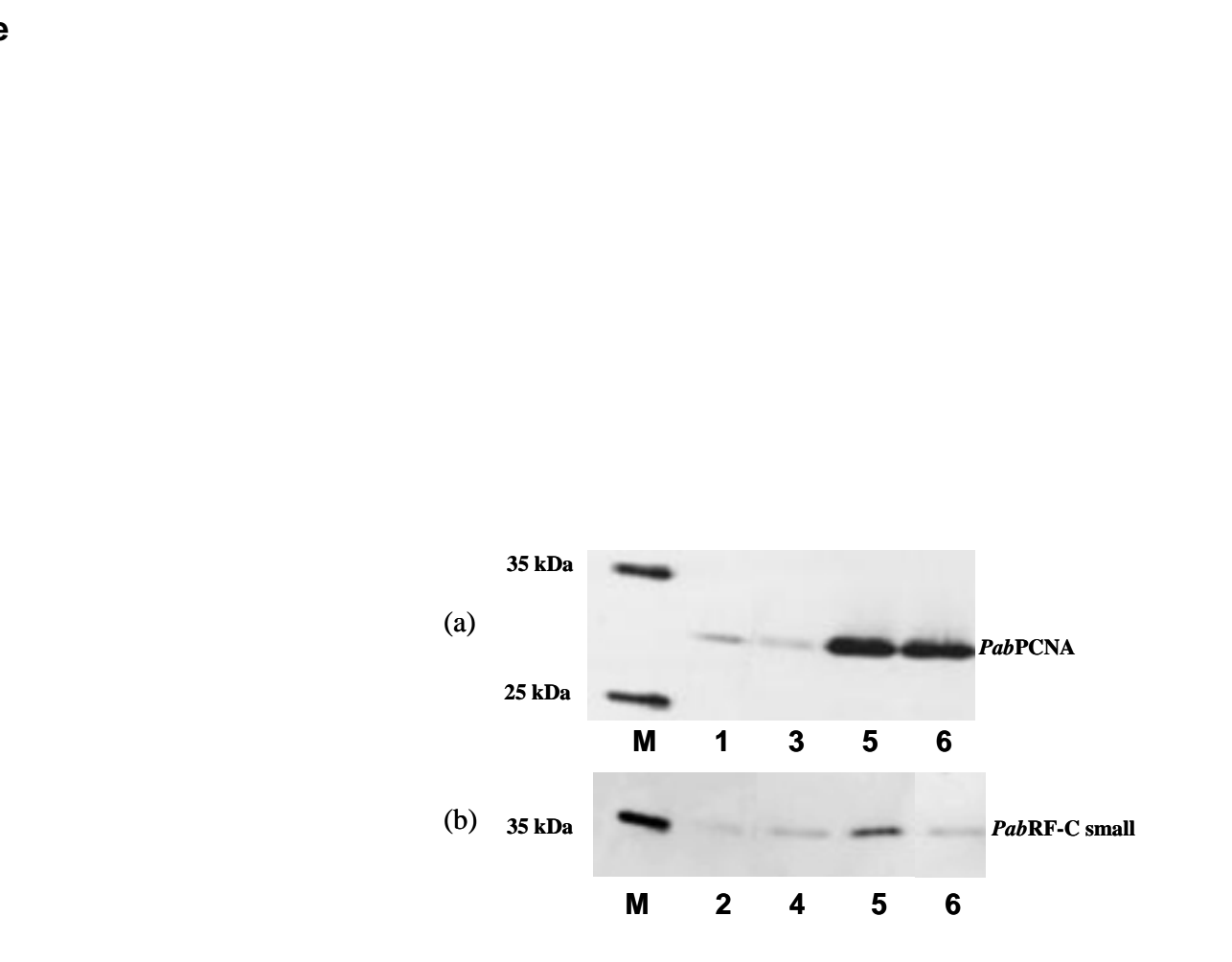

\section{(}

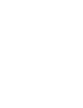

\footnotetext{
(2)

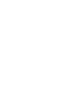

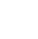

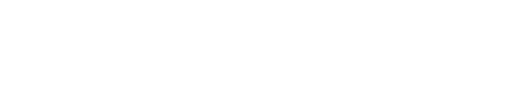

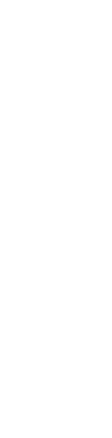


(a)

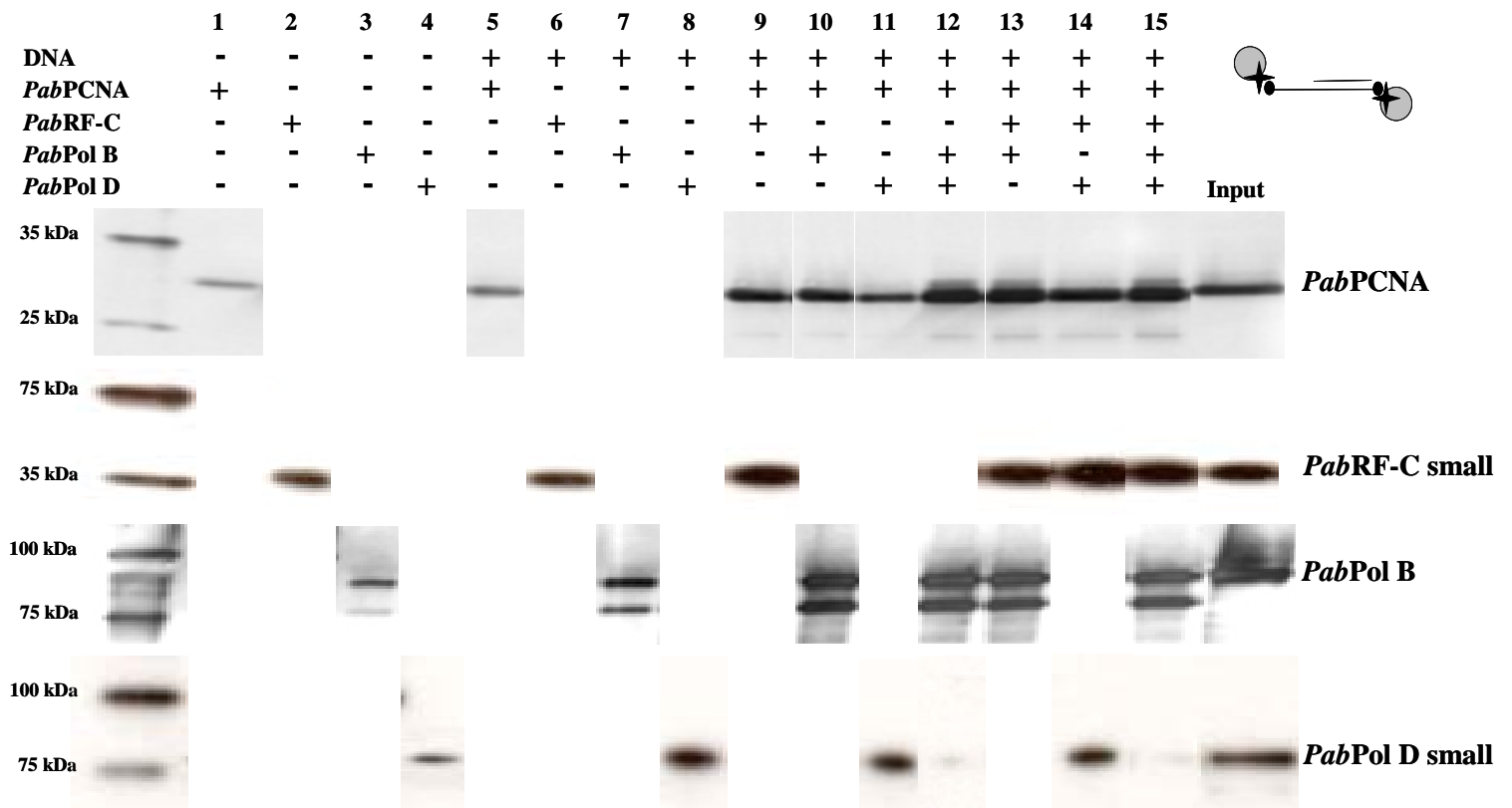


(b)
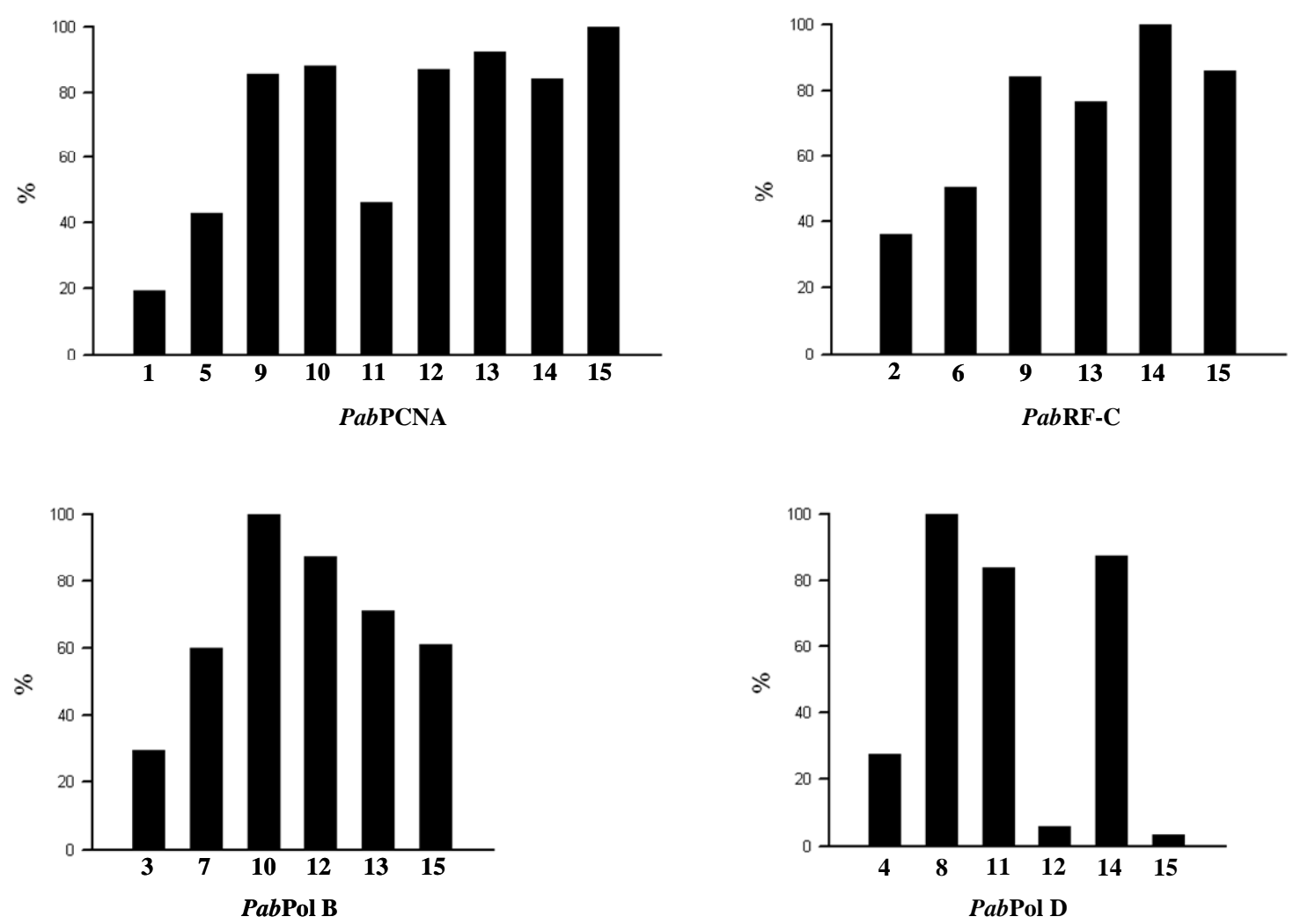